\title{
PREVENTION OF SUCCINYLCHOLINE-INDUCED HYPERKALAEMIA BY MAGNESIUM SULFATE*
}

\author{
J. Antonio Aldrete, M.D., Andres Zahler, M.D., And Jerry K. Aikawa, M.D.†
}

Pharmacological and clinical studies have shown that the onset of the muscle relaxant action of succinylcholine is manifested by unco-ordinated muscular contractions termed fasciculations. ${ }^{1}$ These have been interpreted as manifestations of the augmented response of the muscle unit to excitation elicited by end-plate depolarization, and are usually followed by an increase of serum potassium concentration, ${ }^{2}$ apparently due to loss of the ion from muscle fibres at the onset of membrane depolarization. ${ }^{3}$ In efforts to prevent fasciculations and elevation of serum $\mathrm{K}^{+}$, the rate and route of administration of succinylcholine have been altered and various drugs have been concomitantly used. ${ }^{4-6}$

An evaluation of the alleged anaesthetic properties of magnesium in dogs suggested that electroencephalographic changes were observed only when arterial blood magnesium reached levels which caused myocardial depression, arterial hypotension, central venous pressure elevation, and respiratory muscle paralysis. These effects were reversed by the administration of calcium chloride or neostigmine. ${ }^{7}$ Thus, in addition to its cardiovascular depressant effects, magnesium behaved similarly to curare-like drugs.

This study was intended to evaluate the effect of the previous injection of magnesium on the incidence of muscle fasciculations and to observe the changes of serum $\mathrm{K}^{+}, \mathrm{Mg}^{++}$, and $\mathrm{Ca}^{++}$subsequent to succinylcholine injection. Note was also taken of any other side effects that the combination of both substances might have produced in man undergoing induction of general anaesthesia.

\section{Materials and Methods}

Ninety unselected male patients between the ages of 25 and 58 were studied during the induction of general anaesthesia for various elective surgical procedures (ASA physical status classification 1 and $2 \ddagger$ ). A preoperative visit was made in every case. The patients were fasted for at least eight hours and received for preanaesthetic medication meperidine $\mathrm{HCl}, 1 \mathrm{mg} / \mathrm{kg}$, and atropine sulfate, 0.6 mg intramuscularly, approximately 45-60 minutes prior to induction.

Control readings of arterial blood pressure were obtained by means of a cuff placed on one of the arms and read according to the Riva Rocci method. The heart rate was followed by a precordial stethoscope. Lead 2 of a tripolar electrocardiogram was monitored throughout the procedure.

"From the Divisions of Anaesthesiology and Laboratory Medicine, University of Colorado Medical Center and Veterans Administration Hospital, Denver, Colorado.

†Dr. Aldrete is now in the Department of Anesthesiology, University of Miami School of Medicine, Miami, Florida. Dr. Zahler is deceased.

\American Society of Anaesthesiologists. Newsletter. 27: 6 (February 1963). 


\section{Observation of incidence of fasciculation}

In 60 patients an indwelling catheter was introduced into a vein of one the upper extremities. Control readings of blood pressure and heart rate were obtained. Following at least three minutes of preoxygenation, one gram of magnesium sulfate was rapidly injected intravenously. Sixty seconds later, the blood pressure and heart rate were again recorded and the subject was asked how he felt. Ninety seconds after the injection of $\mathrm{MgSO}_{4}, 4 \mathrm{mg} / \mathrm{kg}$ of thiopental sodium was injected intravenously in a 2.5 per cent solution. Thirty seconds later, $1 \mathrm{mg} / \mathrm{kg}$ succinylcholine chloride was administered by the same route. Endotracheal intubation was performed and thereafter inhalation anaesthetics were administered. The onset and intensity of muscle fasciculations in the upper half of the body were noted.

\section{Determination of serum calcium, magnesium, and potassium}

In the other 30 patients, a control $5 \mathrm{ml}$ venous sample was obtained at the time of insertion of the indwelling catheter. A second $5 \mathrm{ml}$ venous sample was withdrawn five minutes after $\mathrm{MgSO}_{4}$ injection either from the opposite arm or from one jugular vein.

The subjects included in this part of the study were divided into five groups of six patients each, which were managed as follows: (a) The patients were induced in the sequence already listed. (b) Two grams of $\mathrm{MgSO}_{4}$ were injected followed by sodium thiopental and succinylcholine. (c) Administration of $\mathrm{MgSO}_{4}$ was omitted. (d) $\mathrm{MgSO}_{4}$ was replaced by $3 \mathrm{mg}$ of d-tubocurarine. (e) $\mathrm{MgSO}_{4}$ and thiopental were given, but without succinylcholine and the patients were not intubated.

The frequency of muscle fasciculations in the first four groups was observed. Blood aliquots were centrifuged soon thereafter and the serum separated from the cell mass. The determination of serum $\mathrm{Ca}^{++}$and $\mathrm{Mg}^{++}$was performed on a Perkins-Elmer Model 303 atomic absorption spectrophotometer. Absorption by $\mathrm{Mg}^{++}$was read at 286 millimicrons; absorption by $\mathrm{Ca}^{++}$at 212 millimicrons. Serum potassium determinations were made with a flame-photometer.

\section{RESULTS}

Group observed for incidence of muscle fasciculations and other side effects

Of the 60 patients receiving $1 \mathrm{gm} \mathrm{MgSO}_{4}$ /sodium thiopental/succinylcholine in whom blood samples were not obtained, 18 (30 per cent) had no muscle fasciculations, and in 24 others ( 40 per cent), they were mild and brief. In the remaining 18 patients ( 30 per cent), fasciculations appeared to have the usual intensity and duration.

Effects on blood pressure, heart rate, and electrocardiogram. In 17 patients (28 per cent), the arterial blood pressure reading one minute after $\mathrm{MgSO}_{4}$ administration was 10 to 15 per cent lower than the control reading. No change was noted in 43 individuals. Acceleration of heart rate from 10-15 per cent was observed in eight patients ( 13 per cent) one minute after $\mathrm{MgSO}_{4}$ injection. No 
apparent changes were evident in the electrocardiogram tracing of any of the patients studied.

Other side effects. When the patients were asked how they felt one minute after $\mathrm{MgSO}_{4}$ administration, 22 reported feeling "hot all over." Twelve more patients had a localized sensation of "warmth" either in the lower abdomen, genitalia, or glutei. None felt that this symptom was annoying, neither did they appear to have changes in skin colour that would suggest vasodilation. No other symptoms or signs were noted.

Determination of serum $\mathrm{Ca}^{++}, \mathrm{Mg}^{++}$, and $\mathrm{K}^{+}$in patients induced by different methods

The results of serum $\mathrm{Ca}^{++}, \mathrm{Mg}^{++}$, and $\mathrm{K}^{+}$determinations before induction and five minutes thereafter are shown in Tables $I$ to $V$. The intravenous administration of $\mathrm{MgSO}_{4}$, either I gm (Table I) or $2 \mathrm{gm}$ (Table II) preceding thiopental and succinylcholine produced a rise in serum $\mathrm{Mg}^{++}$and decreases in serum $\mathrm{Ca}^{++}$and $\mathrm{K}^{+}$concentrations. These changes were consistent, even in patients who fasciculated as usual, or who had mild and short-lasting fasciculations.

Of these 12 patients, three fasciculated in the usual fashion, two had mild and short-lasting fasciculations, and seven patients did not fasciculate.

Group $c$ included patients induced with thiopental and succinylcholine only. All of them fasciculated and had a mean elevation of serum potassium of 0.35 $\mathrm{mEq} / \mathrm{L}$, ranging from 0.1 to $1.0 \mathrm{mEq} / \mathrm{L}$ (Table III).

Patients in group $d$, in whom $\mathrm{MgSO}_{4}$ was replaced by $3 \mathrm{mg}$ of d-tubocurarine (Table IV) showed slight alterations of serum $\mathrm{K}^{+}$, with the exception of patient 21, who also fasciculated mildly; little or no changes of serum $\mathrm{Ca}^{++}$and $\mathrm{Mg}^{++}$ were observed.

Finally, the six patients receiving $\mathrm{MgSO}_{4}$ and thiopental (group $e$ ) did not fasciculate (Table V); they had elevations of serum $\mathrm{Mg}^{++}$averaging $1.11 \mathrm{mEq}$ and decrease of serum $\mathrm{Ca}^{+}+$and $\mathrm{K}^{+}$similar to groups $a$ and $b$ although not of the same magnitude and consistency.

Other observations. In these 30 patients, no electrocardiographic alterations were observed during induction of anaesthesia. Three patients who received $\mathrm{MgSO}_{4}$ had decreases of arterial blood pressure values between 10 and 15 per cent from the initial reading. After $\mathrm{MgSO}_{4}$ administration, heart rate increased 10 per cent in five patients. The sensation of "getting warm all over" was felt by nine individuals.

\section{Discussion}

Neuromuscular transmission can be partly or completely inhibited by several mechanisms. Among these are: $(a)$ the affecting of nerve impulse transmission (by deep ether anaesthesia), (b) inhibition of acetylcholine synthesis (with hemicolinium 3), (c) excessive cholinesterase activity, (d) reduction of muscle end-plate membrane sensitivity to $\mathrm{ACh}$ (by such drugs as curare), $(e)$ prolonged depolarization of the receptor end-plate (as with succinylcholine), and $(f)$ reduction of the number of $\mathrm{ACh}$ quanta released by the nerve action potential (either by loss of $\mathrm{Ca}^{++}$or by excess $\mathrm{Mg}^{++}$). 
TABLE I

Group A*

\begin{tabular}{|c|c|c|c|c|c|c|c|c|}
\hline & \multicolumn{6}{|c|}{ Patient number } & \multirow[b]{2}{*}{ Means } & \multirow[b]{2}{*}{ s.E. } \\
\hline & 1 & 2 & 3 & 4 & 5 & 6 & & \\
\hline $\begin{array}{l}\text { Calcium } \dagger \\
\text { control } \\
5 \text { minutes }\end{array}$ & $\begin{array}{r}10.2 \\
9.3\end{array}$ & $\begin{array}{l}9.8 \\
9.3\end{array}$ & $\begin{array}{r}10.0 \\
9.7\end{array}$ & $\begin{array}{l}8.4 \\
8.2\end{array}$ & $\begin{array}{l}8.8 \\
8.3\end{array}$ & $\begin{array}{l}8.1 \\
7.7\end{array}$ & $\begin{array}{l}9.22 \\
8.75\end{array}$ & $\begin{array}{l}.400 \\
.436\end{array}$ \\
\hline $\begin{array}{l}\text { Magnesium } \dagger \\
\text { control } \\
5 \text { minutes }\end{array}$ & $\begin{array}{l}2.05 \\
2.50\end{array}$ & $\begin{array}{l}1.85 \\
2.41\end{array}$ & $\begin{array}{l}2.1 \\
2.9\end{array}$ & $\begin{array}{l}1.85 \\
2.05\end{array}$ & $\begin{array}{l}2.0 \\
2.9\end{array}$ & $\begin{array}{l}1.7 \\
2.5\end{array}$ & $\begin{array}{l}1.92 \\
2.54\end{array}$ & $\begin{array}{l}.0801 \\
.0148\end{array}$ \\
\hline $\begin{array}{l}\text { Potassium } \\
\text { control } \\
5 \text { minutes } \\
\text { Muscle fasciculations }\end{array}$ & $\begin{array}{r}5.2 \\
4.5 \\
+++\end{array}$ & $\begin{array}{l}4.7 \\
4.2 \\
----\end{array}$ & $\begin{array}{r}4.7 \\
4.2 \\
\text { mild, }\end{array}$ & $\begin{array}{l}4.9 \\
4.4 \\
+++\end{array}$ & $\begin{array}{r}4.9 \\
4.4 \\
---\end{array}$ & $\begin{array}{l}3.9 \\
3.5 \\
---\end{array}$ & $\begin{array}{l}4.71 \\
4.20\end{array}$ & $\begin{array}{l}.209 \\
.190\end{array}$ \\
\hline
\end{tabular}

*Patients received $1 \mathrm{gm} \mathrm{MgSO}+$ sodium thiopental $4 \mathrm{mg} / \mathrm{kg}+$ succinylcholine $1 \mathrm{mg} / \mathrm{kg}$.

†Values represent $\mathrm{mEq} / \mathrm{L}$ in serum.

TABLE II

Group B*

\begin{tabular}{|c|c|c|c|c|c|c|c|c|}
\hline & \multicolumn{6}{|c|}{ Patient number } & \multirow[b]{2}{*}{ Means } & \multirow[b]{2}{*}{ S.E. } \\
\hline & 7 & 8 & 9 & 10 & 11 & 12 & & \\
\hline \multicolumn{9}{|l|}{ Calcium } \\
\hline control & 8.7 & 9.3 & 9.3 & 8.2 & 8.7 & 10.2 & 9.06 & 0.334 \\
\hline 5 minutes & 7.6 & 7.7 & 7.7 & 5.5 & 7.6 & 9.3 & 7.56 & 0.548 \\
\hline \multicolumn{9}{|l|}{ Magnesium $\dagger$} \\
\hline $\begin{array}{l}\text { control } \\
5 \text { minutes }\end{array}$ & 1.8 & 1.9 & 1.8 & 1.75 & 1.8 & 1.83 & 1.83 & 0.270 \\
\hline \multicolumn{9}{|l|}{ Potassium $\dagger$} \\
\hline control & 4.4 & 4.1 & 4.1 & 4.1 & 4.4 & 4.1 & 4.20 & 0.167 \\
\hline $\begin{array}{l}5 \text { minutes } \\
\text { Muscle fasciculations }\end{array}$ & 3.2 & 4.0 & 4.0 & 4.4 & 4.2 & 3.7 & 3.91 & 0.190 \\
\hline Muscle fasciculations & --- & $\begin{array}{l}\text { mild, } \\
\text { short }\end{array}$ & --- & +++ & --- & --- & & \\
\hline
\end{tabular}

*Patients received $\mathrm{MgSO}_{4} 2$ gms + sodium thiopental $4 \mathrm{mg} / \mathrm{kg}+$ succinylcholine $1 \mathrm{mg} / \mathrm{kg}$.

†Values represent $\mathrm{mEq} / \mathrm{L}$ in serum.

TABLE III

Group c*

\begin{tabular}{|c|c|c|c|c|c|c|c|c|}
\hline & \multicolumn{6}{|c|}{ Patient number } & \multirow[b]{2}{*}{ Means } & \multirow[b]{2}{*}{ S.E. } \\
\hline & 13 & 14 & 15 & 16 & 17 & 18 & & \\
\hline $\begin{array}{l}\text { Calcium } \dagger \\
\text { control } \\
5 \text { minutes }\end{array}$ & $\begin{array}{l}9.5 \\
7.9\end{array}$ & $\begin{array}{l}7.25 \\
7.0\end{array}$ & $\begin{array}{l}9.5 \\
7.9\end{array}$ & $\begin{array}{l}8.9 \\
9.0\end{array}$ & $\begin{array}{l}8.9 \\
7.3\end{array}$ & $\begin{array}{l}10.2 \\
10.5\end{array}$ & $\begin{array}{l}9.04 \\
8.26\end{array}$ & $\begin{array}{l}0.466 \\
0.577\end{array}$ \\
\hline $\begin{array}{l}\text { Magnesium } \\
\text { control } \\
5 \text { minutes }\end{array}$ & $\begin{array}{l}2.1 \\
1.7\end{array}$ & $\begin{array}{l}1.85 \\
1.90\end{array}$ & $\begin{array}{l}1.95 \\
1.65\end{array}$ & $\begin{array}{l}1.85 \\
1.80\end{array}$ & $\begin{array}{l}1.75 \\
1.43\end{array}$ & $\begin{array}{l}1.9 \\
1.95\end{array}$ & $\begin{array}{l}1.90 \\
1.73\end{array}$ & $\begin{array}{l}0.202 \\
0.370\end{array}$ \\
\hline $\begin{array}{l}\text { Potassium } \dagger \\
\text { control } \\
5 \text { minutes } \\
\text { Muscle fasciculations }\end{array}$ & $\begin{array}{r}3.9 \\
4.1 \\
+++\end{array}$ & $\begin{array}{l}4.6 \\
4.7 \\
+++\end{array}$ & $\begin{array}{l}3.9 \\
4.1 \\
+++\end{array}$ & $\begin{array}{l}4.1 \\
5.1 \\
+++\end{array}$ & $\begin{array}{l}2.6 \\
3.2 \\
+++\end{array}$ & $\begin{array}{r}4.1 \\
4.2 \\
+++\end{array}$ & $\begin{array}{l}3.86 \\
4.21\end{array}$ & $\begin{array}{l}0.313 \\
0.296\end{array}$ \\
\hline
\end{tabular}

*Patients received sodium thiopental $4 \mathrm{mg} / \mathrm{kg}+$ succinylcholine $1 \mathrm{mg} / \mathrm{kg}$.

tValues represent $\mathrm{mEq} / \mathrm{L}$ in serum. 
TABLE IV

GROUP D*

\begin{tabular}{|c|c|c|c|c|c|c|c|c|}
\hline & \multicolumn{6}{|c|}{ Patient number } & \multirow[b]{2}{*}{ Means } & \multirow[b]{2}{*}{ S.E. } \\
\hline & 19 & 20 & 21 & 22 & 23 & 24 & & \\
\hline $\begin{array}{l}\text { Calciumt } \\
\text { control } \\
5 \text { minutes }\end{array}$ & $\begin{array}{l}8.6 \\
8.5\end{array}$ & $\begin{array}{l}9.6 \\
9.6\end{array}$ & $\begin{array}{l}8.5 \\
7.4\end{array}$ & $\begin{array}{l}6.1 \\
9.6\end{array}$ & $\begin{array}{l}8.9 \\
9.0\end{array}$ & $\begin{array}{l}10.0 \\
10.2\end{array}$ & $\begin{array}{l}8.61 \\
9.05\end{array}$ & $\begin{array}{l}0.627 \\
0.428\end{array}$ \\
\hline $\begin{array}{l}\text { Magnesium } \dagger \\
\text { control } \\
5 \text { minutes }\end{array}$ & $\begin{array}{l}0.0 \\
2.75 \\
1.9\end{array}$ & $\begin{array}{l}9.0 \\
1.7 \\
1.3\end{array}$ & $\begin{array}{l}2.4 \\
2.25\end{array}$ & $\begin{array}{l}9.0 \\
2.25 \\
2.05\end{array}$ & $\begin{array}{l}9.0 \\
1.8 \\
1.7\end{array}$ & $\begin{array}{r}1.7 \\
1.4\end{array}$ & $\begin{array}{l}9.00 \\
2.07 \\
1.75\end{array}$ & $\begin{array}{l}0.420 \\
0.183 \\
0.166\end{array}$ \\
\hline $\begin{array}{l}\text { Potassium } \dagger \\
\text { control } \\
5 \text { minutes }\end{array}$ & $\begin{array}{l}4.9 \\
4.4\end{array}$ & $\begin{array}{l}3.8 \\
4.5\end{array}$ & $\begin{array}{l}6.9 \\
3.6\end{array}$ & $\begin{array}{l}3.8 \\
4.0\end{array}$ & $\begin{array}{l}3.9 \\
3.8\end{array}$ & $\begin{array}{l}4.2 \\
4.3\end{array}$ & $\begin{array}{l}4.58 \\
4.10\end{array}$ & $\begin{array}{l}0.526 \\
0.179\end{array}$ \\
\hline Muscle fasciculations & & --- & $\begin{array}{l}\text { mild, } \\
\text { short }\end{array}$ & --- & --1 & -- & & \\
\hline
\end{tabular}

"Patients received d-tubocurarine $3 \mathrm{mg}+$ sodium thiopental $4 \mathrm{mg} / \mathrm{kg}+$ succinylcholine $1 \mathrm{mg} / \mathrm{kg}$.

†Values represent $\mathrm{mEq} / \mathrm{L}$ in serum.

TABLE V

GROUP E*

\begin{tabular}{|c|c|c|c|c|c|c|c|c|}
\hline & \multicolumn{6}{|c|}{ Patient number } & \multirow[b]{2}{*}{ Means } & \multirow[b]{2}{*}{ S.E. } \\
\hline & 25 & 26 & 27 & 28 & 29 & 30 & & \\
\hline $\begin{array}{l}\text { Calcium } \\
\text { control } \\
5 \text { minutes }\end{array}$ & $\begin{array}{l}9.1 \\
7.6\end{array}$ & $\begin{array}{l}8.2 \\
7.5\end{array}$ & $\begin{array}{l}9.5 \\
9.2\end{array}$ & $\begin{array}{r}10.3 \\
9.0\end{array}$ & $\begin{array}{l}9.9 \\
9.05\end{array}$ & $\begin{array}{r}10.5 \\
9.1\end{array}$ & $\begin{array}{l}9.58 \\
8.56\end{array}$ & $\begin{array}{l}0.510 \\
0.409\end{array}$ \\
\hline $\begin{array}{l}\text { Magnesium } \dagger \\
\text { control } \\
5 \text { minutes }\end{array}$ & $\begin{array}{l}2.3 \\
2.9\end{array}$ & $\begin{array}{l}2.0 \\
2.35\end{array}$ & $\begin{array}{l}2.9 \\
4.4\end{array}$ & $\begin{array}{l}2.8 \\
4.0\end{array}$ & $\begin{array}{l}1.93 \\
2.85\end{array}$ & $\begin{array}{l}1.90 \\
4.0\end{array}$ & $\begin{array}{l}2.30 \\
3.41\end{array}$ & $\begin{array}{l}0.0448 \\
0.0346\end{array}$ \\
\hline $\begin{array}{l}\text { Potassium } \\
\text { control } \\
5 \text { minutes } \\
\text { Muscle fasciculations }\end{array}$ & $\begin{array}{r}3.8 \\
3.7 \\
---\end{array}$ & $\begin{array}{l}2.0 \\
3.4 \\
---\end{array}$ & $\begin{array}{r}5.7 \\
5.1 \\
----\end{array}$ & $\begin{array}{r}4.4 \\
3.7 \\
---\end{array}$ & $\begin{array}{l}4.8 \\
4.5 \\
---\end{array}$ & $\begin{array}{r}5.3 \\
4.3 \\
---\end{array}$ & $\begin{array}{l}4.33 \\
4.11\end{array}$ & $\begin{array}{l}0.590 \\
0.296\end{array}$ \\
\hline
\end{tabular}

${ }^{*}$ Patients received $1 \mathrm{gm} \mathrm{MgSO}_{4}+$ sodium thiopental $4 \mathrm{mg} / \mathrm{kg}$.

†Values represent $\mathrm{mEq} / \mathrm{L}$ in serum.

In this study, an attempt was made to clarify some of the possible interrelations among the last three mechanisms. An obvious objection to the interpretation of serum electrolyte values is that they do not necessarily represent intracellular concentrations. Nevertheless, a correlation could be established between the sequence of administration of various agents and the trend observed in the difference in concentration of some of the serum electrolytes.

With regard to neuromuscular transmission, the magnesium ion has peculiar differences from and similarities to those of calcium and potassium. Increased $\mathrm{Mg}^{++}$or $\mathrm{K}^{+}$and decreased $\mathrm{Ca}++$ concentrations would partially block the release of acetylcholine quanta from the neural end-plate. This effect can be reversed by the addition of calcium. ${ }^{8}$ In contrast, increased $\mathrm{Ca}^{++}$and $\mathrm{Mg}^{++}$ concentrations can elevate the depolarization threshold of a nerve or muscle fibre. Clinically, hypomagnesaemia is manifested by increased muscle tone, trismus and tetany, caused by heightened neuromuscular activity almost identical to that seen 
with hypocalcaemia. ${ }^{9}$ In contrast, elevated serum $\mathrm{Mg}^{++}$concentrations in serum causes muscle weakness, decreased reflex tone, and cardiac arrhythmias, all of which can also occur in hypokalaemia.

When $\mathrm{MgSO}_{4}$ was injected intravenously into 60 patients before administration of thiopental and succinylcholine, 18 patients had muscle fasciculations of usual intensity and duration. In 24 patients these fasciculations were weak and of short duration. In 18 others fasciculations were not apparent. These observations suggested that $\mathrm{MgSO}_{4}$ might have acted similarly to non-depolarizing muscle relaxants (d-tubocurarine or gallamine) and partly or wholly inhibited depolarization of the muscle end-plate.

As demonstrated by Meltzer and Auer ${ }^{10}$ and later confirmed by Bryant and collaborators ${ }^{11}$ and Aldrete et al., ${ }^{7}$ the muscle relaxation produced by $\mathrm{MgSO}_{4}$ administration can be antagonized by calcium or neostigmine. The action of the former is interpreted as being due to increased release of acetylcholine from the nerve ending. The latter, by its anticholinesterase effect, would allow accumulation of $\mathrm{ACh}$ and thereby re-establish neuromuscular transmission.

The interaction of $\mathrm{MgSO}_{4}$ with both depolarizing and non-depolarizing muscle relaxants has been previously suggested. Morris and Giesecke ${ }^{\mathbf{2}}$ noted that preeclamptic women treated with $\mathrm{MgSO}_{4}$ and undergoing caesarian section required lesser amounts of muscle relaxants than when $\mathrm{MgSO}_{4}$ was not used. Giesecke et $a l .{ }^{13}$ using a nerve-muscle preparation of the cat, confirmed an additive effect of $\mathrm{MgSO}_{4}$ with d-tubocurarine and succinylcholine.

Our results indicate that the elevation of serum $\mathrm{Mg}^{++}$produced by injection of $\mathrm{MgSO}_{4}$ before succinylcholine, by affecting depolarization, would overshadow the usual elevation of serum $\mathrm{K}^{+}$, not seen in groups $a$ and $b$, even though muscle fasciculations were present or insinuated in 30 per cent and 40 per cent of these patients, respectively.

Comments on other side effects. The slight alterations of blood pressure and heart rate observed one minute after $\mathrm{MgSO}_{4}$ injection are similar to those described in 1916 by Peck and Meltzer ${ }^{14}$ whils attempting to produce anaesthesia in man by infusion of $\mathrm{MgSO}_{4}$. These changes correlate with our findings in dogs at equal serum $\mathrm{Mg}^{++}$concentrations (between 2.5 and $4.4 \mathrm{mEq} / \mathrm{L}$ ).$^{7}$ The patients of Peck and Meltzer also had the sensation of "being hot with flushing of the face." This latter event was not observed in our patients, but there was a difference in dosage. A decrease in peripheral vascular resistance has been suggested by Seller and co-workers as the possible mechanism for the alleged hypotensive action of magnesium. ${ }^{15}$ This hypothesis was proposed to explain the changes of intracellular $\mathrm{K}^{+} / \mathrm{Mg}^{++}$ratios seen in hypertensive patients receiving hydrochlorothiazide therapy, inferring that alterations of magnesium balance might influence vascular reactivity. This same physiological event could be responsible for the very small drops in arterial pressure observed in 20 of the patients ( 25 per cent) who received $\mathrm{MgSO}_{4}$.

The absence of electrocardiographic alterations other than tachycardia was not surprising, since the highest serum $\mathrm{Mg}^{++}$value observed was $4.4 \mathrm{mEq} / \mathrm{L}$, which is below the level at which arrhythmias occur. ${ }^{7,11}$ 


\section{SUMmary}

By the previous intravenous administration of $1 \mathrm{gm}$ of magnesium sulfate, the muscle fasciculations produced by succinylcholine were prevented in 18 (30 per cent) and ameliorated in 24 (40 per cent) of a group of 60 patients induced with sodium thiopental. Serum calcium, magnesium, and potassium concentrations were determined before and five minutes after injection of the drugs. Patients receiving $\mathrm{MgSO}_{4}$ ( 1 or $2 \mathrm{gm}$ ) had increases in $\mathrm{Mg}^{++}$and reduction of $\mathrm{Ca}++$ and $\mathrm{K}^{+}$ even when muscle fasciculations were evident. Thiopental and succinylcholine administration produced slight diminutions of serum $\mathrm{Mg}^{++}$and $\mathrm{Ca}^{++}$and rises of $\mathrm{K}+$. When d-tubocurarine was substituted for $\mathrm{MgSO}_{4}$ in the sequence of injections, muscle fasciculations were hindered, $\mathrm{K}^{+}$values decreased slightly, and $\mathrm{Ca}++$ and $\mathrm{Mg}^{++}$levels were barely altered.

It is inferred that the rise of $\mathrm{Mg}^{++}$concentration in serum resulting after the injection of $\mathrm{MgSO}_{4}$ might impede muscle end-plate depolarization by decreasing the amount of acetylcholine quanta released by the nerve ending, and/or by sensitizing the same receptor site.

\section{RÉSUMÉ}

Par administration préalable de 1 gramme de sulfate de magnésium intraveineux, les fasciculations musculaires produites par la succinylcholine ont été prevénues dans 18 cas ( 30 pour cent) et ameliorées dans 24 cas ( 40 pour cent) chez un group de 60 patients, l'induction étant réalisée par thiopental sodium. Les concentrations de calcium, magnésium et potassium sanguins ont été determinées avant et 5 minutes après injection. Les patients recevant $\mathrm{MgSO}_{4}$ ( 1 ou 2 grammes) ont presenté une augmentation du magnésium et une diminution du calcium et du potassium, même quand les fasciculations musculaires étaient très nettes.

L'administration de thiopental et de succinylcholine produit une légère diminution des taux sériques du magnésium et du calcium et une augmentation du potassium. Quand la d-tubocurarine était substituée au $\mathrm{MgSO}_{4}$ lors des injections, les fasciculations musculaires étaient prévenues, les valeurs du potassium sanguin diminuaient légèrement, et le calcium et le magnésium étaient peu altérés.

Nous pensons que l'augmentation du taux serique du magnésium, secondaire à l'injection de $\mathrm{MgSO}_{4}$ doit agir au niveau de la plaque motrice en créant une dépolarisation par diminution du taux d'acetylcholine liberée par le nerf, et/ou en sensibilisant le recepteur lui-même.

\section{ACKNOWLEDGMENTS}

Technical assistance was provided by Mrs. Beverly Anderson. The magnesium sulfate was supplied by Abbott Laboratories, North Chicago, Illinois.

\section{REFERENCES}

1. Paton, W. D. M. \& Zaimrs, E. J. Methonium Compounds. Pharmacol. Rev. 4: 219 (1952).

2. Stevenson, D. E. Changes in the Blood Electrolytes of Anaesthetized Dogs Caused by Suxamethonium. Brit. J. Anaesth. 32: 364 (1960). 
3. Paton, W. D. M. The Effects of Muscle Relaxants Other Than Muscular Relaxation. Anesthesiology. 20: 453 (1959).

4. Churchiml-Davidson, H. C. Suxamethonium Chloride and Muscle Pain. Brit. Med. J. 1: 74 (1954).

5. Kuupp, $H$. Uber die Freisetzung von Kalium aus der Muskulatur unter der Einwirkung einiger Muskelrelaxentien. Arch. Internat. Pharmacodyn. 98: 340 (1954).

6. Usubiaga, J. E. Prevention of Succinylcholine Fasciculations with Local Anesthetics. Anesthesiology. 26: 3 (1965).

7. Aldrete, J. A.; Barnes, D. R.; \& Aukawa, J. K. Does Magnesium Produce Anesthesia? Evaluation of Its Effects on the Cardiovascular and Neurologic Systems. Anesth. \& Analg. 47: 428 (1968).

8. Elmpuist, D. \& Lambert, D. H. Detailed Analysis of Neuromuscular Transmission in a Patient with Myasthenic Syndrome Sometimes Associated with Bronchogenic Carcinoma. Mayo Clin. Proc. 43: 689 (1968).

9. Arkawa, J. K. The Role of Magnesium in Biologic Processes. Springfield, Illinois: C. C. Thomas (1963).

10. Mectzen, S. J. \& Auer, J. Antagonistic Action of Calcium upon the Inhibitory Effect of Magnesium. Am. J. Physiol, 21: 400 (1908).

11. Bryant, G. W.; Lehmann, G.; \& Knoefel, P. K. The Action of Magnesium on the CNS and Its Antagonism by Calcium. J. Pharmacol. Exper. Therap. 65: 318 (1939).

12. Morris, R. E. \& Giesecke, A. H., JR. Potentiation of Muscle Relaxant by Magnesium Sulfate Therapy in Toxemia of Pregnancy. Southern Med. J. 61: 25 (1968).

13. Giesecke, A. H., Jr.; Morris, R. E.; \& Dalton, M. D. On Magnesium, Muscle Relaxants, Toxemic Parturients, and Cats. Anesth. \& Analg. 47: 689 (1968).

14. PECK, C. H. \& Mertzer, S. J. Anesthesia in Human Beings by Intravenous Injection of Magnesium. J.A.M.A. 67: 1131 (1916).

15. Seller, R. H.; Ramirez-Muxo, O.; \& Brest, A. N. Magnesium Metabolism in Hypertention. J.A.M.A. 191: 654 (1965). 